\title{
Demonstration Projects Using Wick Drains to Stabilize Landslides
}

THE

GEOLOGICAL

SOCIETY

OF AMERICA
PAUL M. SANTI

BRADLEY A. CRENSHAW ${ }^{1}$

Department of Geology and Geological Engineering, Colorado School of Mines, Golden, CO 80401

C. DALE ELIFRITS

Department of Physics and Geology, Northern Kentucky University, Highland Heights, KY 41099
Key Terms: Slope Stability, Slope Stabilization, Landslides, Drainage, Wick Drains

\section{ABSTRACT}

A new method has been developed to stabilize slopes and landslides using driven, geotextile wick drains rather than drilled polyvinyl chloride or steel drains. Compared to drilled horizontal drains, wick drains can be significantly deformed without rupturing. They resist clogging, and they can be installed quickly and economically by workers with no previous training. Since 1998 , more than 170 drains, totaling more than $2,600 \mathrm{~m}(8,600 \mathrm{ft})$ in length, have been installed at eight sites in Missouri, Colorado, and Indiana. At three of the sites, drains were installed at a density and layout considered to be appropriate for full-scale stabilization: 27 to 44 drains were driven at each site, averaging 15 to $20 \mathrm{~m}$ (50-70 ft) in length. A method was developed to accurately estimate the groundwater-table profile after drain installation, and computer slope-stability analysis using this method showed significant increases (10-40 percent) in factors of safety after drain installation. The limitations of the methodology should be recognized: it may be applied in specific situations requiring relatively short $(<30-45 \mathrm{~m}$, or $<100-150 \mathrm{ft}$ ) drains in materials ranging from soft to very stiff (up to $30 \mathrm{blows} / \mathrm{ft}$ in standard penetration tests). The potential effectiveness of drainage as a mitigation option should be verified through analysis of site geology and hydrogeology before drain installation.

${ }^{1}$ Current Address: Jordan, Jones \& Goulding, 6801 Governers Lake Parkway, Norcross, GA 30071.

\section{INTRODUCTION}

A new method has been developed to stabilize slopes and landslides using driven, geotextile (polypropylene) wick drains rather than drilled polyvinyl chloride or steel drains (Santi, 1999; Santi et al. 2001a). Compared to drilled horizontal drains, wick drains can be significantly stretched (as much as 60-100 percent) without rupturing, and they resist clogging (American Wick Drain Corporation, 2002; Nilex Corporation, 2002). Furthermore, they can be installed very rapidly, at rates in excess of 15 to $18 \mathrm{~m} /$ hour (50-60 ft/hour) (Santi et al., 2001b), and very economically, at costs of $\$ 8$ to $\$ 13$ per meter (\$2.50-4.00 per foot) (Santi et al., 2001b). They may be installed by unskilled laborers with a minimal investment in equipment, which the authors estimate at less than $\$ 2,000$. Drains more than $30 \mathrm{~m}(100 \mathrm{ft})$ in length have been installed through materials with standard penetration test values as high as 28 (Santi et al. 2001b).

Since 1998, more than 170 drains, totaling more than 2,600 $\mathrm{m}(8,600 \mathrm{ft})$ in length, have been installed at eight sites in Missouri, Colorado, and Indiana. Five of these sites were considered to be experimental installations, where the equipment and technique were developed and optimized for various geologic materials (Santi et al., 2001b). Three of the sites were considered to be full-scale installation efforts, where the density and layout of drains was considered to be sufficient to significantly enhance the stability of the slopes (Santi and Crenshaw, 2002). The purpose of this paper is to document the stabilization effort, analysis, and effect on slope stability at these three sites.

\section{INSTALLATION METHODOLOGY}

The technique and equipment for installing horizontal wick drains are described in detail by Santi and Elifrits (2000) and by Santi and others (2001b). The installation technique may be summarized as follows: the wick drains are prepared for installation by rolling into long, 


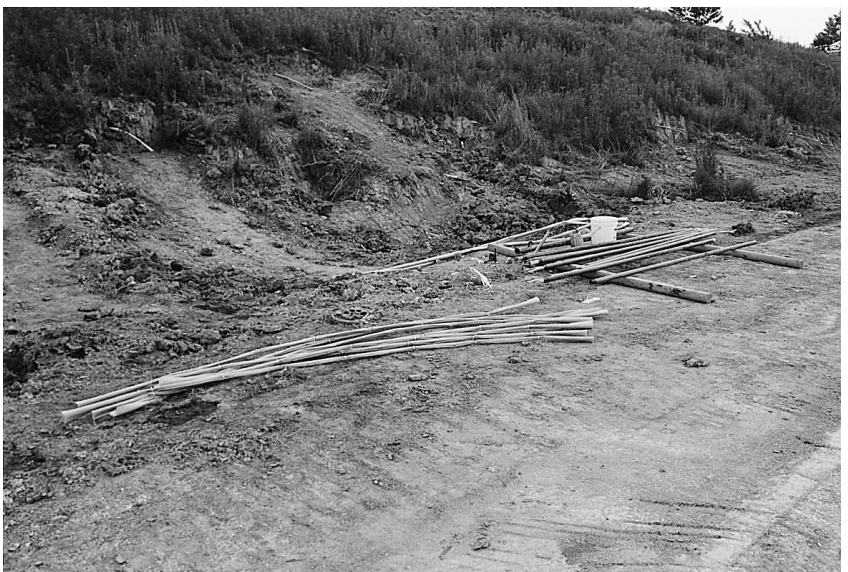

Figure 1. Rolled and tied wick prepared for insertion into drive pipe (foreground) and drive pipe with wick already inserted (background).

tight cylinders and tying at $1-$ to $2-\mathrm{ft}$ intervals with electrical cable ties (the drains are normally $4-\times 100-\mathrm{mm}$ in cross-section and are shipped in 300-m rolls). Cylinders of $3.5 \mathrm{~m}(11 \mathrm{ft})$ in length are inserted into a steel drive pipe, which for this work was a 3-m (10-ft) AQ wire-line drill rod with an inner diameter of $3.5 \mathrm{~cm}$ $\left(1^{3} / 8\right.$ in.) and an outer diameter of $4.44 \mathrm{~cm}\left(1^{3} / 4\right.$ in.) (Figure 1). A disposable drive plate is tied to the lead end of the wick (Figure 2), and the pipe is then pushed into the ground using a bulldozer or backhoe (Figure 3). Additional pipes are driven by splicing the wick sections together (Figure 4), threading the pipes together, and pushing in the new piece of pipe. Pipe sections may be added and driven until the desired drain length is reached or until the driving resistance causes refusal. Once the total length has been driven, the pipes are pulled from the ground while the drive plate anchors the wick in place (Santi et al., 2001b).

\section{EFFECTS OF DRAINS ON THE WATER TABLE}

The most significant effect of the wick drains is to convey water out of the slope and to lower the water table. This effect can be modeled using computer slopestability programs, but the actual location of the water table usually is estimated, is based on readings from relatively few piezometers, or is assumed to exist at the level of the drains. None of these methods is entirely suitable, however, because the true water-table surface is an irregular, corrugated shape, with low troughs along the lengths of the drains and higher ridges between drains. A number of studies have tried to model the water-table surface in these situations (Kenney et al., 1977; Nonveiller, 1981; Choi, 1983; Lau and Kenney, 1984; Nakamura, 1988; and Liljegren, 2000). The methods in these studies are difficult to use because they are too complex for widespread use, assume a level of

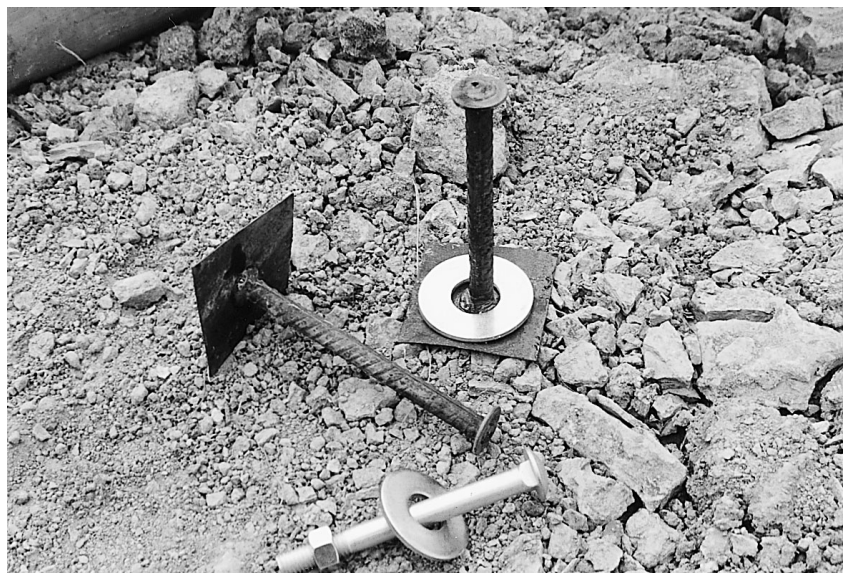

Figure 2. Drive plates to be attached to the front end of the wick. Plates are designed to wrap around the drive pipe during pushing and to anchor the wick in place during pipe withdrawal. A support washer may be used to strengthen the plate for stiff materials, or the carriage bolt and washer may be used for rocky materials.

homogeneity of the landslide soils that is unrealistic and inaccurate, or rely on parameters that are difficult to measure (e.g., flow-boundary conditions and locations of water-table intercept with drains).

As a consequence, one of the goals of this study was to develop a method of estimating the water-table surface using easily measured parameters and presented in a format that would not be intimidating for most users. The method contains four steps, which are described in more detail by Crenshaw and Santi (in press) and are summarized briefly below. In general, the objective of the method is to convert the irregular water-table surface and irregular spacing of fanned drains into an average value for each so that slope-stability analysis of a single crosssection more accurately represents conditions across the slope as a whole.

First, inhomogeneity of drain spacing was assessed by calculating the average spacing for $3-\mathrm{m}(10-\mathrm{ft})$ intervals up the axis of the landslide, as shown in Figure 5. In this way, users are free to install drains where access is good, to install additional drains where water seems to be concentrated, and to calculate properly the effects of the drains using the average spacing.

Second, the shape of the water table along the length of an individual drain was observed using four laboratory test cells containing wick drains in soil and several piezometers along the length of the drains. These observations demonstrated that the water table coincided with the drain along most of its length, except at the deep end of the drain. The departure of the water table from the drain increased with increasing water percolation through the soil above the drain.

Third, the shape of the water table between drains was calculated based on work by Hooghoudt (original work in 


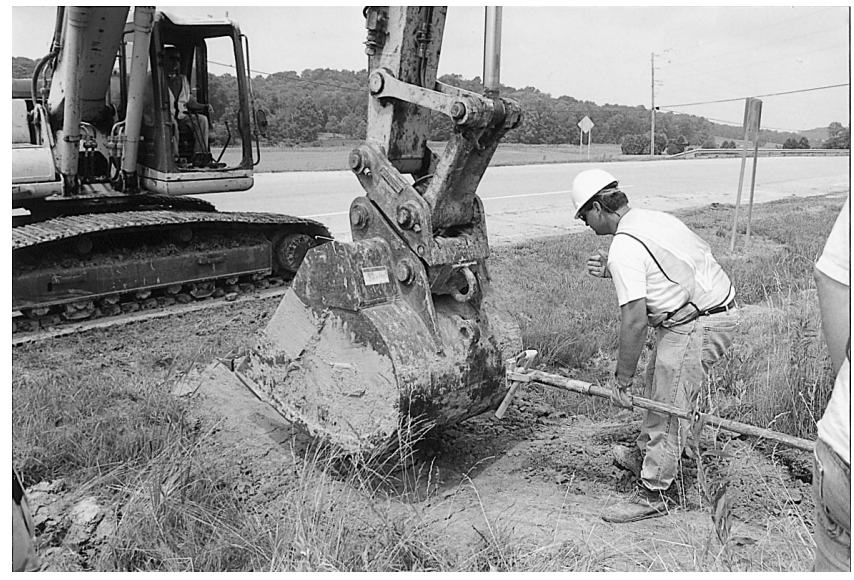

Figure 3. Pushing a drain in place using a trackhoe excavator.

Dutch), as summarized by Luthin (1966), that described water levels between agricultural drains. In simplest terms, the relationship between drain spacing, soil characteristics, and height of the water table may be expressed as

$$
S^{2}=\frac{4 K H}{v}(2 d+H)
$$

where $S$ is the drain spacing, $K$ is the soil hydraulic conductivity, $H$ is the maximum height of the water table above the profile determined in step two (this value occurs at the mid-point between two drains), $v$ is the recharge rate (estimated as the average rate of water flow from the drains), and $d$ is the depth to bedrock (adjusted by an equivalency factor).

Fourth, the corrugated surface between drains described in step 3 was converted to an average water-table height above the drain by integrating the equation above (adjusted for proper limits of integration) and then dividing the resulting area by the spacing between drains. An approximate solution to estimate the average watertable height, $H_{\text {avg }}$, is

$$
H_{\mathrm{avg}}=\pi \frac{s}{8} \sqrt{\frac{v}{K}}-d
$$

Crenshaw and Santi (in press) present a more accurate solution that incorporates the concept of a 'base water table' to account for unequal distribution of recharge throughout the drain field.

\section{DRAIN PLACEMENT DESIGN}

Details of drain layout design, spacing, and orientation are given by Santi and others (2001a, 2001b). In general,

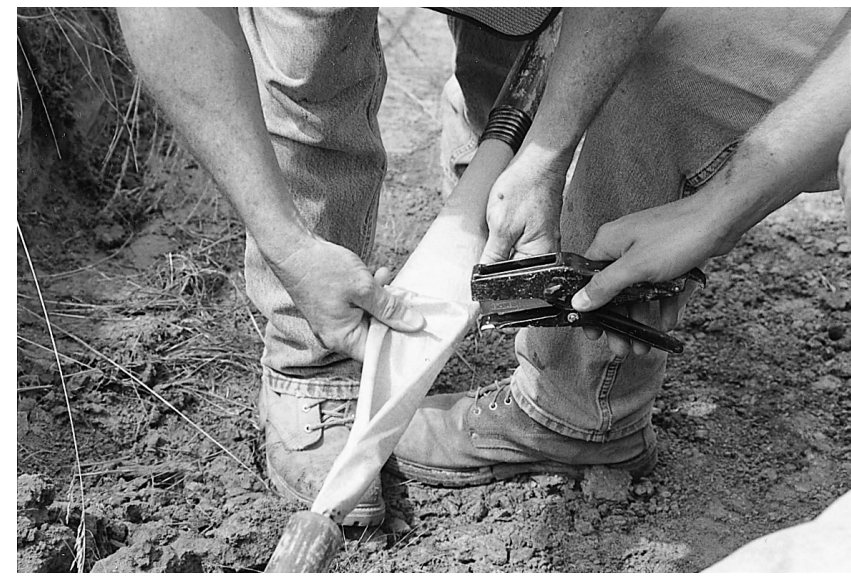

Figure 4. Wick sections may be spliced using a standard plier stapler.

the cited authors found that drain placement was usually dictated by site access conditions, so it was generally more convenient and less disruptive to fan out several drains from a single outlet location. Outlet locations were usually 10 to $20 \mathrm{ft}$ apart. When a drain clearly intercepted a pocket of water in a permeable zone in the landslide, additional flanking drains were installed to maximize the drainage of this area. The flanking drains were oriented $5^{\circ}$ to $10^{\circ}$ away from the original drain. The procedure outlined in the previous section helps the user to convert the fan pattern into an average drain spacing for computer analysis. Drains from a single fan may be easily bundled and fed into a single, protected outlet pipe, for which the authors used corrugated plastic irrigation hose with a diameter of $10 \mathrm{~cm} \mathrm{(4} \mathrm{in.).}$

\section{DEMONSTRATION PROJECTS}

Experimental drain installations were conducted at five sites to develop and optimize both equipment and technique for various geologic materials (Santi et al., 2001b). These sites included a constructed, instrumented test embankment in Rolla, Missouri; a natural, clayey silt loess slope near St. Joseph, Missouri; and clayey fill slopes near Rye, Rio Blanco, and Meeker, Colorado. Three full-scale demonstration projects, where the density and layout of drains was considered to be sufficient to significantly enhance the stability of the slopes, were completed near Jasper, Indiana; Boonville, Missouri; and Meeker, Colorado (Santi and Crenshaw, 2002). These projects were completed with assistance from the respective Departments of Transportation in each state. Presented below is a summary of the geology, drain installation, and stability analysis for each of the fullscale demonstration projects. Slope stability was analyzed by the Modified Bishop Method using the computer program PCSTABL5 with the pre- and post-processor STEDWin (Annapolis Engineering Software). 


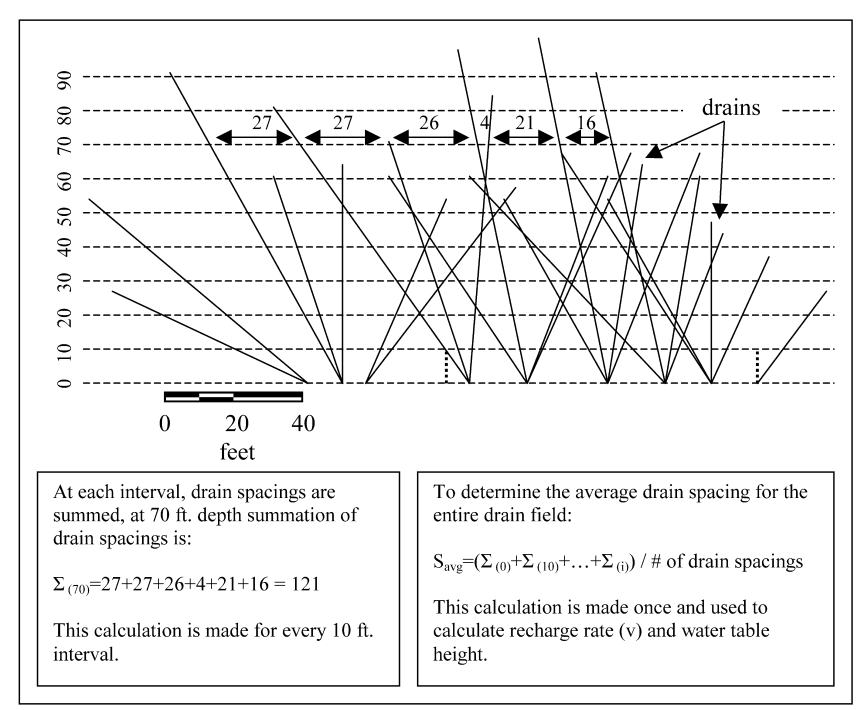

Figure 5. Example calculation of average drain spacing $(1 \mathrm{ft}=0.305 \mathrm{~m})$.

Jasper, Indiana

\section{Setting}

This site is located on the east side of State Highway 545 at $4.8 \mathrm{~km}(3 \mathrm{mi})$ south of Dubois, Indiana, which is close to the larger town of Jasper (Figure 6). The slope is above State Highway 545, and slope movement has repeatedly uplifted the shoulder of the roadway. A small retaining wall was installed during the late 1980s, and the north end of the wall has overturned because of insufficient embedment of the supporting piers.

The failure occurs in a natural slope consisting of as

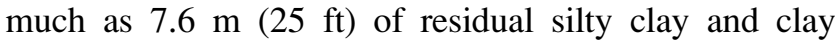
overlying weathered limestone, shale, and sandstone. The ditch at the toe of the landslide adjacent to the roadway shoulder contains ponded water and significant growth of hydrophilic vegetation.

The slide mass has multiple scarps and tension cracks, and the top of the slide has a graben feature, which the authors interpret as being caused by extension of the slide mass away from the hillside. A sewer line runs through this graben, and according to a geologist from the Indiana Department of Transportation (INDOT) (Chase, 2000), the sewer line has been broken and replaced at least twice. The interpretation of whether sewer leakage initiated the landslide or landslide movement caused the sewer leakage is an on-going issue of concern for INDOT.

Because of the evidence for long-term water drainage and numerous fissures through which surface water may enter the landslide, it appears that high water levels in the slope have contributed to instability.

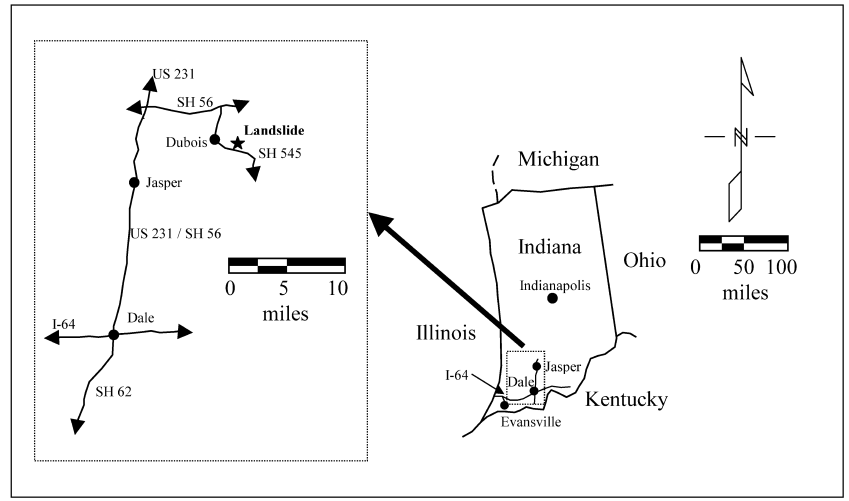

Figure 6. Location of the landslide analyzed near Jasper, Indiana $(1 \mathrm{mi}=$ $1.61 \mathrm{~km})$.

\section{Drain Installation}

Forty-four drains, totaling $800 \mathrm{~m}(2,613 \mathrm{ft})$ in length, were installed at the site over a period of nine working days during June 2000 (drain locations are shown in Figure 7) using a Komatsu PC200LC trackhoe. The length of some of the drains was limited because of their proximity to the sewer line. Sixteen of the drains produced water immediately after installation. As close as the authors can estimate, 19 more produced water after rainfall, and nine were permanently dry. (Individual drains could not be monitored after installation, because the drains were bundled into irrigation pipes, which were partially buried.) Drainage was observed from every outlet pipe in June 2001, a year after drain installation.

\section{Landslide Analysis}

To assist in analysis of the landslide, two slope inclinometers and eight piezometers were installed in the slide mass. Soil samples from the borings were tested in INDOT's laboratory for tri-axial compressive strength, grain-size distribution, Atterberg limits, unit weight, and water content. A summary of the values used for slope stability analysis is included in Table 1 (in places, generalized values from reference literature, calibrated as closely as possible to laboratory values and backcalculated values, are used).

Inclinometers and piezometers were monitored for 6 months after their installation in June and July 2000. In summary, the inclinometers have shown less than $4 \mathrm{~mm}$ of total movement near the top of the slope (3-SI in Figure 7) and less than $2 \mathrm{~mm}$ of movement near the middle of the slope (2-SI in Figure 7).

The only piezometers that were installed before the wick drains, which could theoretically record a drop in water level because of the drains, are TP-2, TP-3, and TP-5 (Figure 7). A drop in water level in excess of $1 \mathrm{~m}(3$ $\mathrm{ft}$ ) was measured in TP-2, which is located within $1.5 \mathrm{~m}$ 


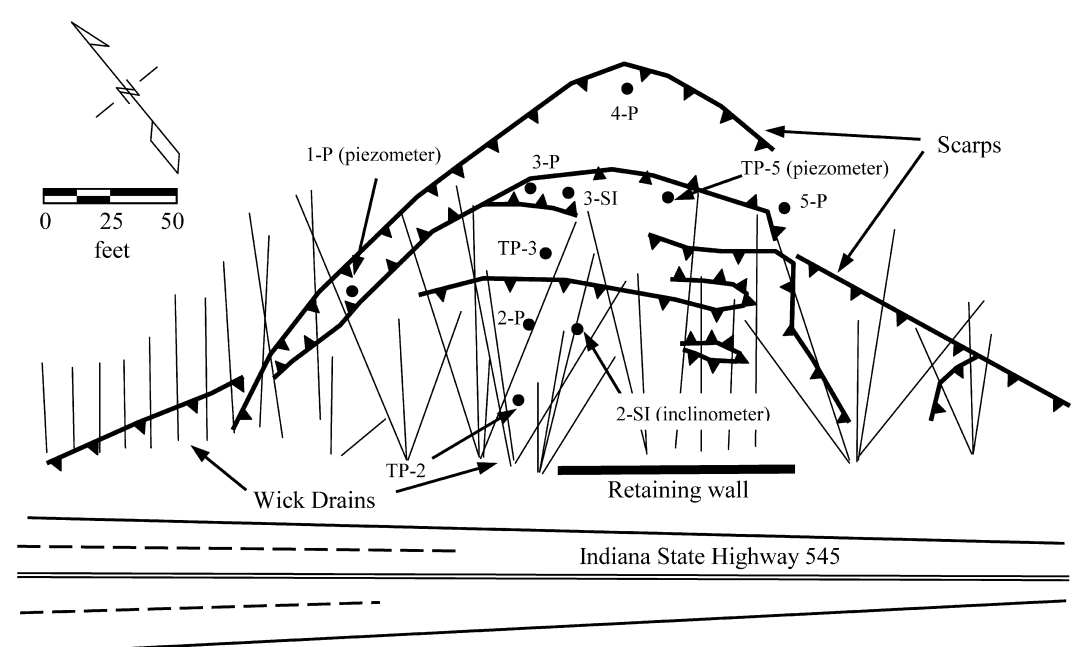

Figure 7. Map of the Jasper, Indiana, landslide. Surface scarps as well as locations of installed wick drains, piezometers, and inclinometers are shown $(1 \mathrm{ft}=0.305 \mathrm{~m})$.

(5 ft) of two wick drains. Piezometer TP-3 was dry on installation and has shown only a trace of water since July 2000, so the effect of the wick drains could not be tracked. Piezometer TP-5 showed a steady increase in water level $(>3 \mathrm{~m}$, or $>10 \mathrm{ft})$ after installation. Because this piezometer is located more than $4.5 \mathrm{~m}(>15 \mathrm{ft})$ from a wick drain, we expect the influence of the drain to be minimal.

Other piezometers at the site (1-P, 2-P, 3-P, 4-P, and 5-P) were installed several weeks after the drains were placed, because the drilling contractor could not begin the work when planned in early June 2000. These piezometers have not shown substantial changes in water levels since late June 2000, although 1-P, 2-P, and 5-P are close to wick drains and the water level in those areas likely is lower than in early June.

For computer stability analysis of the landslide, three conditions were evaluated: stability under normal groundwater conditions, stability with high groundwater (assumed to represent conditions that have caused periodic movement of the slope), and stability with drains installed (and high groundwater):

1. Stability of the slope under normal groundwater conditions with no drains installed. Figure 8 shows the results of the analysis under typical conditions with a low groundwater table, producing a factor of safety against sliding of 1.24. The groundwater levels for this set of conditions were assumed to match those measured during the dry summer months (Figure 8).

2. Stability of the slope under high groundwater conditions with no drains installed. Figure 8 shows the groundwater levels required to initiate slope movement, producing a factor of safety of 0.99 . These groundwater levels are those that are anticipated during heavy rainfall. The model was calibrated to this set of conditions because the factor of safety could be assumed to equal 1.00. High groundwater levels were estimated assuming inflow from the graben at the top of the slope and outflow at the ditch line, with a smooth water-table surface following the topography between these two end points (Figure 8).

3. Stability of the slope under high groundwater conditions but after wick-drain installation. The resulting minimum factor of safety in this case was 1.42 , which represents an 11 percent increase over current conditions and a 43 percent increase over critical high groundwater conditions. This analysis assumed that the wick drains fix groundwater levels, even during wet periods, because they provide a constant outlet point for water in the slope. Stability with wick drains installed was evaluated by adjusting the groundwater table to equal:

a. The levels measured in piezometers located close to the analyzed cross-section (2-SI and 3-SI in Figure 7),

b. The elevation of the two wicks intercepting the cross-section (shown in Figure 8), and

c. The elevation calculated between the wicks using the equations presented earlier.

Boonville, Missouri

Setting

This site is located on the south side of eastbound Interstate 70 at $0.4 \mathrm{~km}(1 / 4 \mathrm{mi}$ ) east of exit 101 (which is State Route 5) (Figure 9). The slope drops off below and to the south of eastbound I-70, and the asphalt in the 
Table 1. Summary of geotechnical parameters used in slope-stability analysis (parameters in British units as required for the computer slope-stability model; $C L$ is a low plasticity clay and GM is a silty gravel).

\begin{tabular}{|c|c|c|c|}
\hline Site/Layer & $\begin{array}{l}\text { Geotechnical } \\
\text { Property }\end{array}$ & Value & Basis \\
\hline \multicolumn{4}{|l|}{ Jasper, Indiana } \\
\hline \multirow{3}{*}{$1 \mathrm{CL}$} & Unit weight & $121 \mathrm{pcf}$ & Laboratory tests \\
\hline & Cohesion & $20 \mathrm{psf}$ & $\begin{array}{l}\text { Laboratory triaxial tests showed } 180 \text { psf at peak strength; value was reduced to } \\
\text { nominally low value to represent residual strength }\end{array}$ \\
\hline & Friction angle & $22^{\circ}$ & $\begin{array}{l}\text { Laboratory triaxial tests showed } 27^{\circ} \text { at peak strength; back-calculation showed } 22^{\circ} \\
\text { ( } 75 \% \text { of peak), which is within the reasonable range for residual strength }\end{array}$ \\
\hline \multirow[t]{3}{*}{2 Shale } & Unit weight & $120 \mathrm{pcf}$ & Reference table in Hoek and Bray (1981) \\
\hline & Cohesion & $2000 \mathrm{psf}$ & Reference table in Hoek and Bray (1981); reduced to represent weathered material \\
\hline & Friction angle & $35^{\circ}$ & Reference table in Hoek and Bray (1981) \\
\hline \multicolumn{4}{|c|}{ Boonville, Missouri } \\
\hline \multirow[t]{3}{*}{$1 \mathrm{CL}$} & Unit weight & $97 \mathrm{pcf}$ & $\begin{array}{l}\text { Reference table in Coduto (2001); high end of range selected, because it is } \\
\text { a compacted clay }\end{array}$ \\
\hline & Cohesion & $155 \mathrm{psf}$ & $\begin{array}{l}\text { Laboratory direct shear tests showed } 225 \text { psf at peak strength; value was reduced by } \\
30 \% \text { to represent residual strength }\end{array}$ \\
\hline & Friction angle & $17^{\circ}$ & $\begin{array}{l}\text { Laboratory direct shear tests showed } 21.5^{\circ} \text { at peak strength; value was reduced by } \\
20 \% \text { to represent residual strength }\end{array}$ \\
\hline \multirow[t]{3}{*}{2 Cobbles } & Unit weight & $115 \mathrm{pcf}$ & $\begin{array}{l}\text { Reference table in Coduto (2001); considered a poorly graded gravel with significant } \\
\text { cobbles and boulders }\end{array}$ \\
\hline & Cohesion & $10 \mathrm{psf}$ & Nominally small value to reflect presence of clay between coarse particles \\
\hline & Friction angle & $25^{\circ}$ & $\begin{array}{l}\text { Reference table in U.S. Navy (1986); assumed poorly graded gravel at } 50 \% \text { relative } \\
\text { density, lowered } 5^{\circ} \text { because of presence of silt and clay and the rounded shape of } \\
\text { coarse grains }\end{array}$ \\
\hline \multirow[t]{3}{*}{$3 \mathrm{CL}$} & Unit weight & $97 \mathrm{pcf}$ & $\begin{array}{l}\text { Reference table in Coduto (2001); high end of range selected, because it is } \\
\text { a compacted clay }\end{array}$ \\
\hline & Cohesion & $165 \mathrm{psf}$ & $\begin{array}{l}\text { Laboratory direct shear tests showed } 260 \text { psf at peak strength; value was reduced by } \\
35 \% \text { to represent residual strength, confirmed by back-calculation }\end{array}$ \\
\hline & Friction angle & $15^{\circ}$ & $\begin{array}{l}\text { Laboratory direct shear tests showed } 16^{\circ} \text { at peak strength; value was reduced by } 7 \% \\
\text { to represent residual strength, confirmed by back-calculation }\end{array}$ \\
\hline \multirow[t]{3}{*}{4 Limestone } & Unit weight & $160 \mathrm{pcf}$ & Reference table in Hoek and Bray (1981) \\
\hline & Cohesion & $3 e 5$ psf & Reference table in Hoek and Bray (1981) \\
\hline & Friction angle & $40^{\circ}$ & Reference table in Hoek and Bray (1981) \\
\hline \multicolumn{4}{|c|}{ Meeker, Colorado } \\
\hline \multirow[t]{3}{*}{$1 \mathrm{GM}$} & Unit weight & $125 \mathrm{pcf}$ & $\begin{array}{l}\text { Reference table in Coduto (2001); considered a silty gravel; high end of range } \\
\text { selected, because it is compacted }\end{array}$ \\
\hline & Cohesion & $45 \mathrm{psf}$ & $\begin{array}{l}\text { Nominally small value to reflect presence of clay between coarse particles; adjusted } \\
\text { by back-calculation }\end{array}$ \\
\hline & Friction angle & $30^{\circ}$ & $\begin{array}{l}\text { Reference table in U.S. Navy (1986); assumed mixture of silt and gravel at } 75 \% \\
\text { relative density, lowered } 5^{\circ} \text { based on back-calculation }\end{array}$ \\
\hline \multirow[t]{3}{*}{$2 \mathrm{CL}$} & Unit weight & $110 \mathrm{pcf}$ & Laboratory tests \\
\hline & Cohesion & $660 \mathrm{psf}$ & $\begin{array}{l}\text { Laboratory tests showed a minimum peak strength of } 1,100 \mathrm{psf} \text {; based on } \\
\text { back-calculation, residual strength value of } 660 \mathrm{psf}(60 \% \text { of peak) was considered } \\
\text { to be reasonable }\end{array}$ \\
\hline & Friction angle & $13^{\circ}$ & $\begin{array}{l}\text { Slight decrease }\left(2.3^{\circ}\right) \text { from laboratory values to represent residual strength; confirmed } \\
\text { by back-calculation }\end{array}$ \\
\hline \multirow[t]{3}{*}{3 Siltstone } & Unit weight & $120 \mathrm{pcf}$ & Reference table in Hoek and Bray (1981) \\
\hline & Cohesion & $1 \mathrm{e} 5 \mathrm{psf}$ & Reference table in Hoek and Bray (1981) \\
\hline & Friction angle & $30^{\circ}$ & Reference table in Hoek and Bray (1981) \\
\hline
\end{tabular}

shoulder lanes is damaged where the failure surface emerges at the top of the slope. The failure occurs in a sandy clay and clay fill soil that was placed to fill a valley and to provide a level roadway surface. The fill is approximately 3 to $5.5 \mathrm{~m}(10-18 \mathrm{ft})$ thick and contains an irregular, sloping cobble and boulder fill layer that is 0.6 to $2 \mathrm{~m}(2-7 \mathrm{ft})$ thick (Figure 10). Underlying the fill layers is interbedded shale and limestone bedrock.

The landslide is steep, sloping approximately $1.5: 1$. It is heavily vegetated during the spring and summer, with 


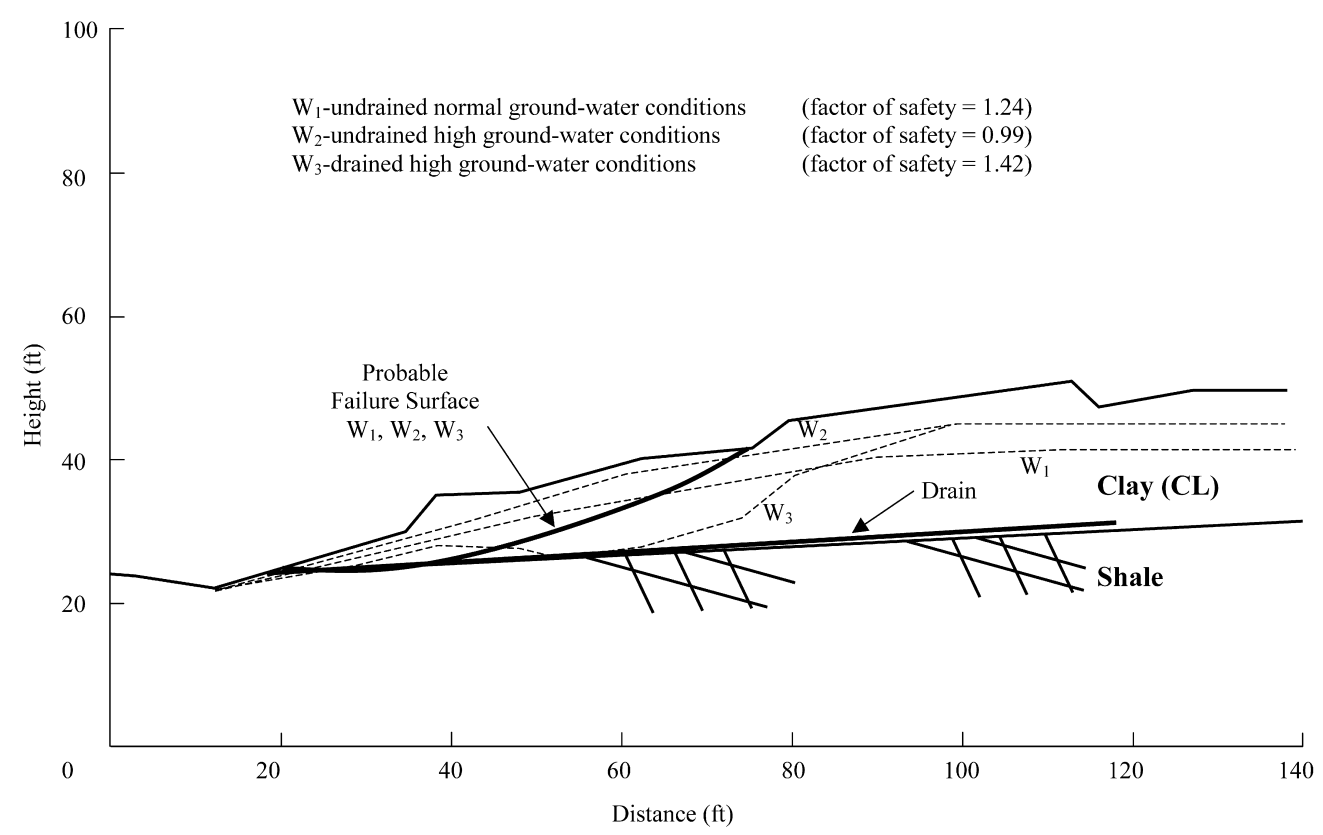

Figure 8. Analysis of the Jasper, Indiana, landslide. Line $\mathrm{W}_{1}$ represents normal groundwater conditions, $\mathrm{W}_{2}$ represents high groundwater conditions (the level required to initiate landslide movement), and $\mathrm{W}_{3}$ represents high groundwater conditions after drain installation. Soil properties are shown in Table 1.

a wet swale along the eastern margin and a creek below the toe of the slope.

Slope movement appears to be caused by high groundwater levels resulting from blockage of the natural canyon drainage by the constructed fill. The wet swale near the slide and thick vegetation on the slide indicate that water is exiting the steep slope face and that drains could intercept much of this water and convey it away from the slope.

\section{Drain Installation}

Ten drains, totaling $76 \mathrm{~m}(249 \mathrm{ft})$ in length, were installed on December 2 and 3, 1998, at three levels near the middle of the Boonville landslide as part of the effort to refine the equipment and technique for installing horizontal wick drains. The installation equipment consisted of a Case 550E bulldozer and a Case 9030B trackhoe. Two of the drains at the upper level began producing small volumes of water overnight. The boulder and cobble zone impeded drain installation in many cases.

Thirty-six drains, totaling $558 \mathrm{~m}(1,832 \mathrm{ft})$ in length, were installed on May 21 through 25, 2001, as shown on Figure 10, with a Case 580 Super L Extendahoe. Two of the drains immediately produced water, and several others were moist. The authors suspect that additional drains began flowing after installation based on observation during September 2001 of water trickling out drain manifolds. As at the Indiana site, however, individual drains could not be monitored after installation, because the drains were bundled and buried, with only a single outlet pipe for several drains. Drainage was observed from 11 of the 18 outlet pipes during April 2002 (eleven months after drain installation).

The average drain length at this site, slightly more than

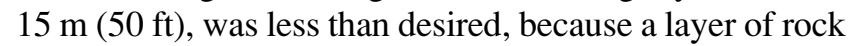
rubble fill within the roadway embankment stopped many of the drains. The location of this rock at the surface, which mimics its presence at depth, is shown on Figure 10.

\section{Landslide Analysis}

Two inclinometers and two piezometers were installed in December 1998 to track slope movement and groundwater levels. By December 2000, the slope inclinometers had shown less than $5 \mathrm{~mm}$ of movement. Because this was after the 1998 installation of 10 short drains and before the 2001 full-scale installation, the authors conclude that the slope was relatively stable during this period, that only minor creep was occurring, and that the 1998 drains contributed little to the stability.

Because the piezometers were installed at the same time as the 1998 drains, the effects of the 1998 drains on the water table could not be measured. Because of water production from drains near the lower piezometers, however, one may assume that wick drains tapped a water pocket in the vicinity. During the 5 days of drain installation during 2001, the water level in the lower piezometer remained constant, but water level in the 


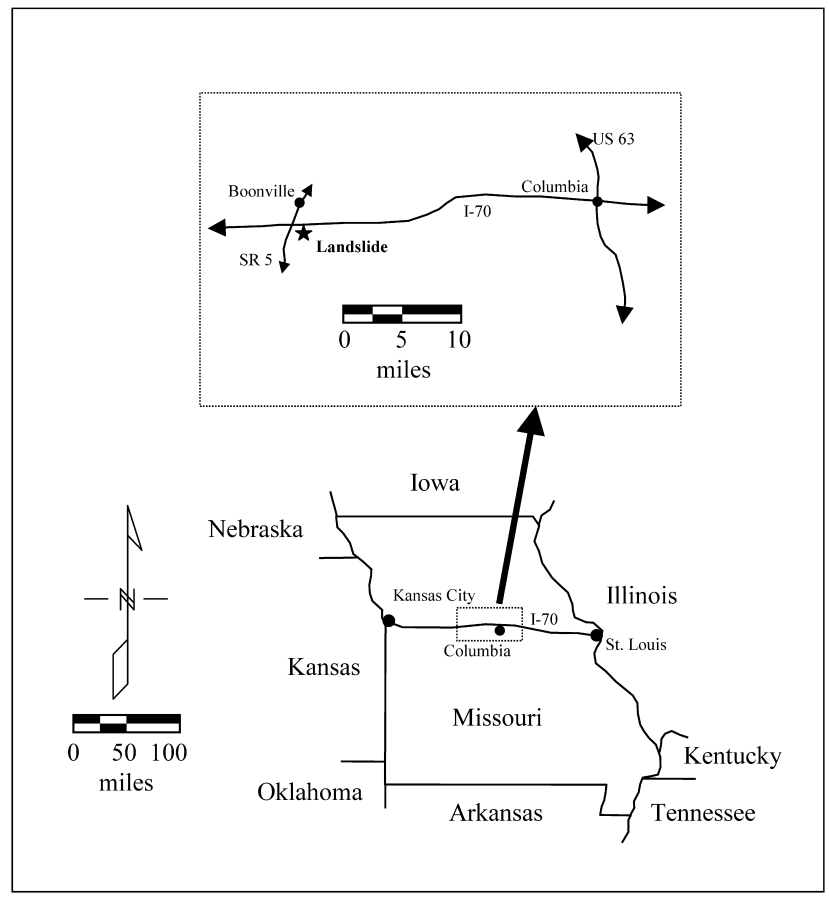

Figure 9. Location of the landslide analyzed near Boonville, Missouri $(1 \mathrm{mi}=1.61 \mathrm{~km})$.

upper piezometer dropped $0.85 \mathrm{~m}(2.8 \mathrm{ft})$, almost certainly as a result of drainage through the wicks.

Computer slope-stability analysis was conducted for the Boonville landslide using topography and stratigraphy developed during field mapping and from boreholes, strength and density values from laboratory tests and standard references (Table 1), and water-table elevations from site piezometers and the modeling process described earlier. Sensitivity analysis and back-calculation procedures were run on the current slope configuration and on the projected pre-failure slope topography to validate the strength values used in the analysis and to estimate the water-table elevations required to initiate slope movement. Next, three additional analyses were run to demonstrate the effects of the wick drains:

1. Stability of the slope under normal groundwater conditions with no drains installed. Figure 11 shows the results of the analysis under typical conditions with a low groundwater table, producing a factor of safety against sliding of 1.14 .

2. Stability of the slope under high groundwater conditions with no drains installed. Figure 11 shows the groundwater levels required to initiate slope movement, producing a factor of safety of 0.99 . These groundwater levels are anticipated during heavy rainfall.

3. Stability of the slope under high groundwater conditions but after wick-drain installation. Even though the wick drains could not all be pushed past the rock rubble layer, Figure 11 shows a factor of safety of 1.08 for high groundwater conditions. This represents a nearly 10 percent increase in stability, and for the conservative analysis parameters used in this study, this improvement is expected to substantially reduce landslide movement and resulting roadway damage (a factor of safety of 1.08 would not usually be acceptable if the input values were not considered to be strongly conservative).

Meeker, Colorado

Setting

This site is located at mile 47.7 on State Highway 13 north of Meeker, Colorado (Figure 12). The slope drops off below and to the east of northbound State Highway 13 , and the asphalt in the roadway is damaged where the failure surface emerges at the top of the slope. The failure occurs in a clay and silty clay fill soil that was placed to fill a valley and to provide a level roadway surface. The fill is approximately 6 to $15 \mathrm{~m}(20-50 \mathrm{ft})$ thick. Overlying the fill is a silty gravel layer $1.5 \mathrm{~m}$ (5 ft) thick, and underlying the fill is siltstone and claystone bedrock.

Slope movement occurs primarily during the spring, when snowmelt raises the regional groundwater level. Movement could also be enhanced by the infiltration of water from an irrigation ditch encircling part of the hill directly northwest of the slide (Pihl, 2000).

\section{Drain Installation}

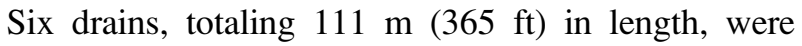
installed in a fan pattern on June 11 and 14, 1999, from the base of the slope below the roadway as part of the effort to refine the equipment and technique for installing horizontal wick drains. The installation equipment consisted of a Caterpillar D4C XL bulldozer. Several of the drains immediately produced water, and one produced a volume as high as $20 \mathrm{~L} /$ minute (5 gallons/ minute) for several days before reducing to a steady trickle. The drain outlet pipe continued to produce water in July 2002 (three years after installation).

Twenty-seven drains, totaling $576 \mathrm{~m}(1,891 \mathrm{ft})$ in length, were installed at the Meeker landslide on June 4 through 7, 2001, as shown on Figure 13. The installation was done with a Caterpillar D4C XL bulldozer. Twelve of the drains immediately produced water, and several others began draining after a few days. Drainage was observed from 5 of the 10 outlet pipes in September 2001 (three months after drain installation) and from three of the outlet pipes in July 2002 (thirteen months after installation and during a severe drought).

The average drain length was more than $21 \mathrm{~m}(70 \mathrm{ft})$, and most drains were stopped when bedrock was 


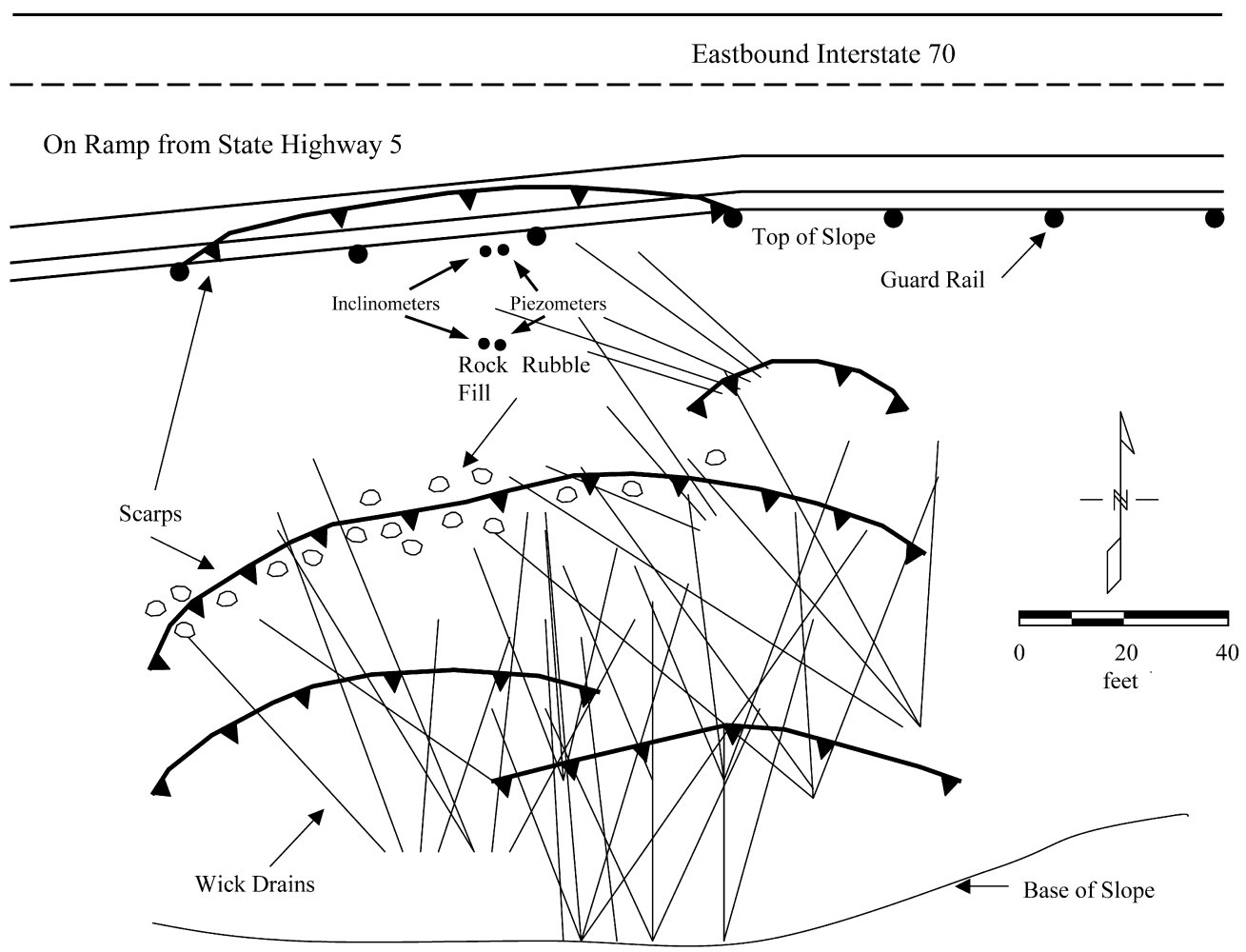

Figure 10. Map of the Boonville, Missouri, landslide. Surface scarps as well as locations of installed wick drains, piezometers, and inclinometers are shown $(1 \mathrm{ft}=0.305 \mathrm{~m})$.

encountered. Several drains reached $30 \mathrm{~m}(100 \mathrm{ft})$ and could have been pushed further, but no more drive pipe was available.

\section{Landslide Analysis}

Three piezometers located within $30 \mathrm{~m}(100 \mathrm{ft})$ of the landslide were installed in the mid-1990s as part of the overall landslide evaluation by the Colorado Department of Transportation. Measured in May 2000, the piezometers showed groundwater at 6.4 to $8.2 \mathrm{~m}(21-27 \mathrm{ft})$ below the roadway surface. These values are useful for slope-stability analysis of the landslide before drains were installed, but the piezometers are located too far away from the wick drains to show any influence from the drains. Furthermore, the piezometers were paved over during the spring of 2001 and could not be used during the latest drain-installation work.

As for the Jasper and Boonville landslides, computerslope stability analysis used topography and stratigraphy developed during field mapping and from boreholes, strength and density values from laboratory tests and standard references (Table 1), and water-table elevations from site piezometers and from the modeling process described earlier. Sensitivity analysis and back-calculation procedures were run on the current slope configuration and on the projected pre-failure slope topography to validate the strength values used in the analysis and to estimate the water-table elevations required to initiate slope movement. Next, three additional analyses were run to demonstrate the effects of the wick drains:

1. Stability of the slope under normal groundwater conditions with no drains installed. Figure 14 shows the results of the analysis under typical conditions with a low groundwater table, producing a factor of safety against sliding of 1.09 .

2. Stability of the slope under high groundwater conditions with no drains installed. Figure 14 shows the groundwater levels required to initiate slope movement, producing a factor of safety of 1.00 . These groundwater levels are anticipated during heavy rainfall.

3. Stability of the slope under high groundwater conditions but after wick-drain installation. The long drains installed at the site had a significant effect on the water-table surface, as shown on Figure 14. This change resulted in a factor of safety of 1.17 , which represents a substantial increase in stability.

\section{DISCUSSION}

Without long-term monitoring of slope movement rates and piezometers located near installed wick drains, 


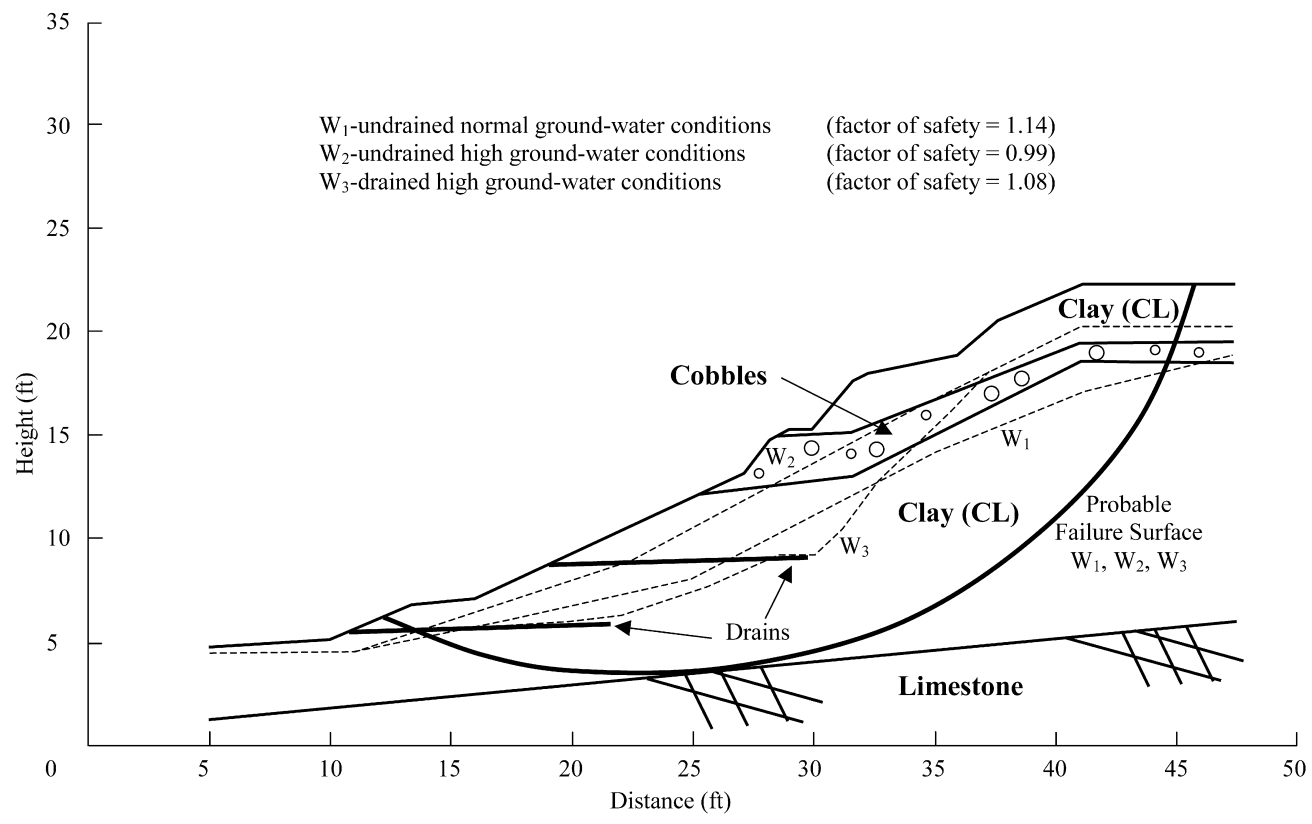

Figure 11. Analysis of the Boonville, Missouri, landslide. Lines $\mathrm{W}_{1}, \mathrm{~W}_{2}$, and $\mathrm{W}_{3}$ are the same as those defined in Figure 8 . Soil properties are shown in Table 1.

it is difficult to conclusively evaluate the effects of the wick drains on slope stability. Neither of these data sets was available for the three demonstration sites. None of the three sites, however, has shown significant movement since drain installation (a period of 2 years at Jasper, IN, and 1 year for Boonville, $\mathrm{MO}$, and Meeker, $\mathrm{CO}$ ) in the form of roadway heave or cracking or the need for roadway maintenance. Both the Boonville and Meeker areas were in the midst of several-year droughts at the time of stabilization, so the slope behavior during a wet year has yet to be observed. The production of water through the drains at these sites, however, even during dry years, indicates drain effectiveness. Many of the drains have continued to produce water long after their installation, and as observed at the Jasper site, nearly all drains produce water immediately after rainfall. Slopestability analysis, using the best evidence available to measure, estimate, or calculate the height of the watertable surface across the slide mass, shows a clear and significant improvement in stability resulting from the effects of the drains on the water table.

The limitations on the methodology should be recognized: it may be applied in specific situations requiring relatively short drains $(<30-45 \mathrm{~m}$, or $<100$ $150 \mathrm{ft}$ ) placed in materials ranging from soft to very stiff (up to 30 blows/ft in standard penetration tests) (Santi et al., 2001b). The potential effectiveness of drainage as a mitigation option should be verified through analysis of site geology and hydrogeology before drain installation.

Drain installation rates and costs are a function of the experience of the installation crew and of the site

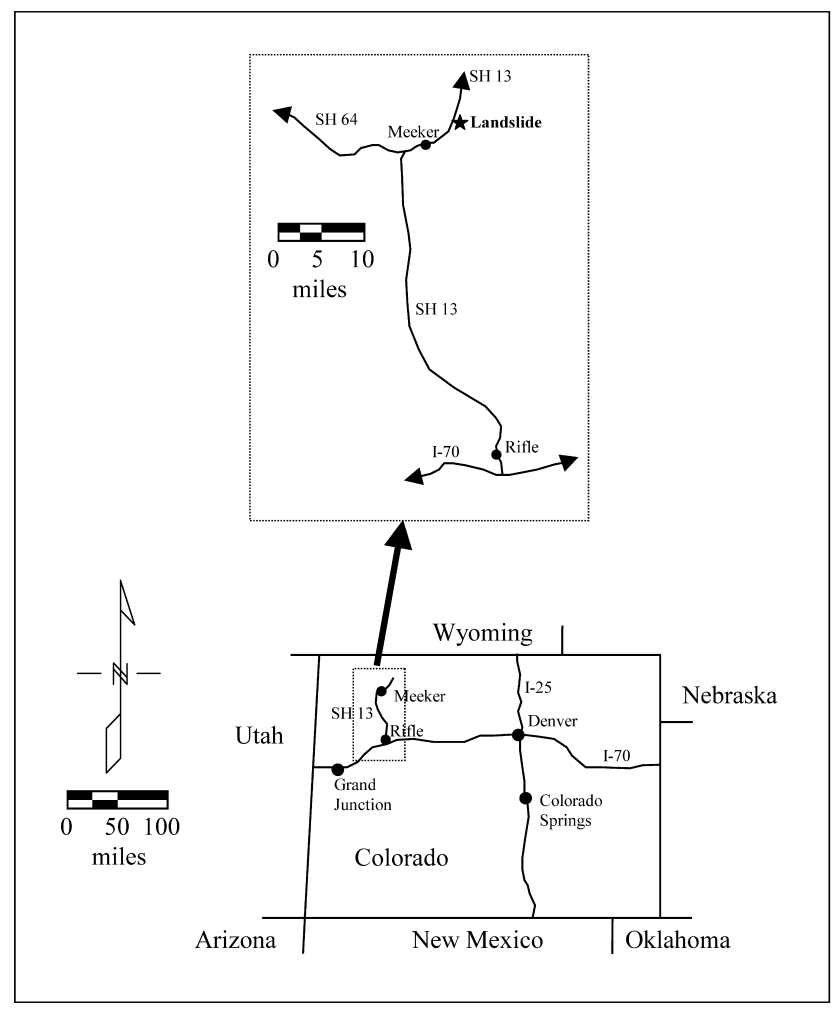

Figure 12. Location of the landslide analyzed near Meeker, Colorado $(1 \mathrm{mi}=1.61 \mathrm{~km})$. 


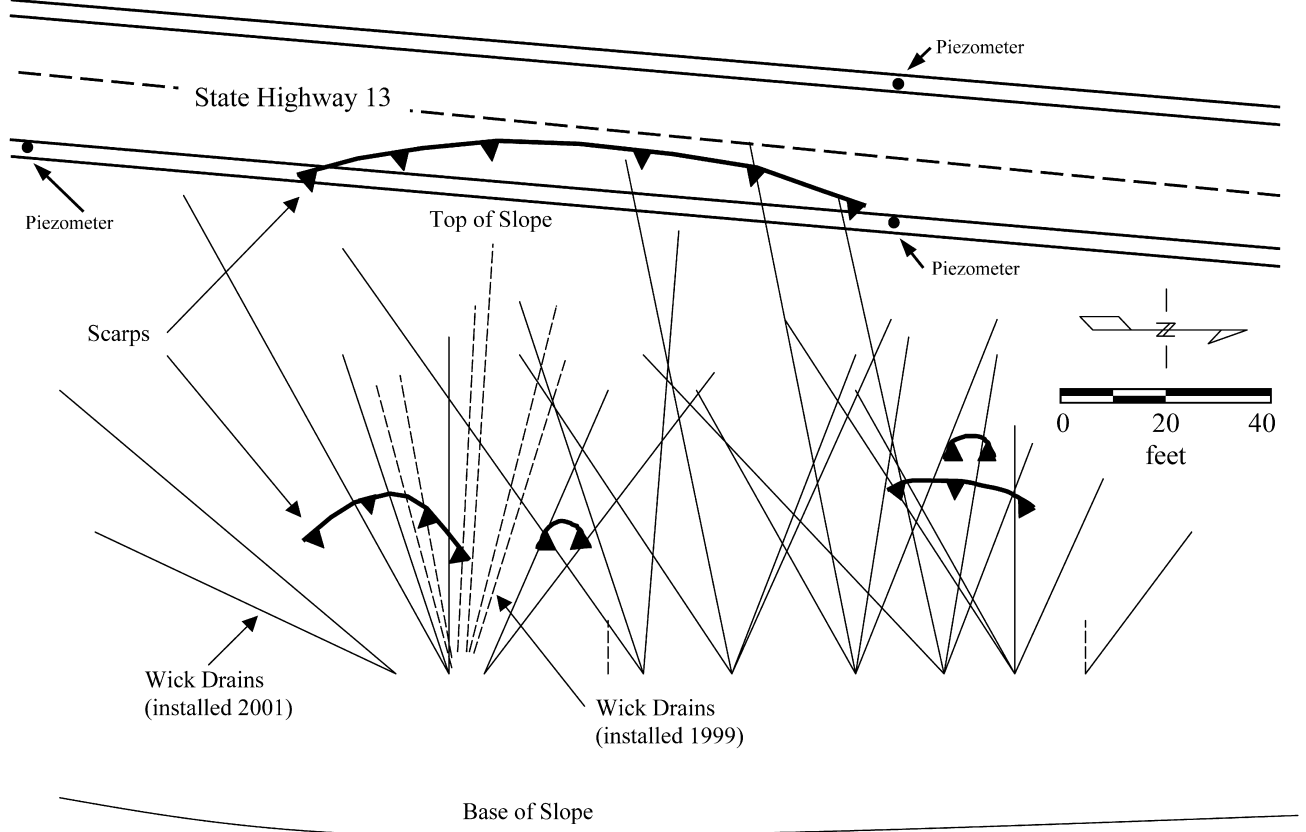

Figure 13. Map of the Meeker, Colorado, landslide. Surface scarps as well as locations of installed wick drains and piezometers are shown $(1 \mathrm{ft}=$ $0.305 \mathrm{~m})$.

geology and layout. On the whole, per-foot costs will decrease, and installation rates will increase, for longer drains installed from a few fan pads rather than from individual pads. Calculations of footage rates made from the three demonstration sites are summarized in Table 2 . These results show continued increase in the rate of installation, as the graduate students directing the operation gained experience. A new crew supplied by the local Department of Transportation was trained at each site.

An estimation of installation costs may be made as follows, assuming $18 \mathrm{~m} /$ hour (0.056 hours $/ \mathrm{m})$ :

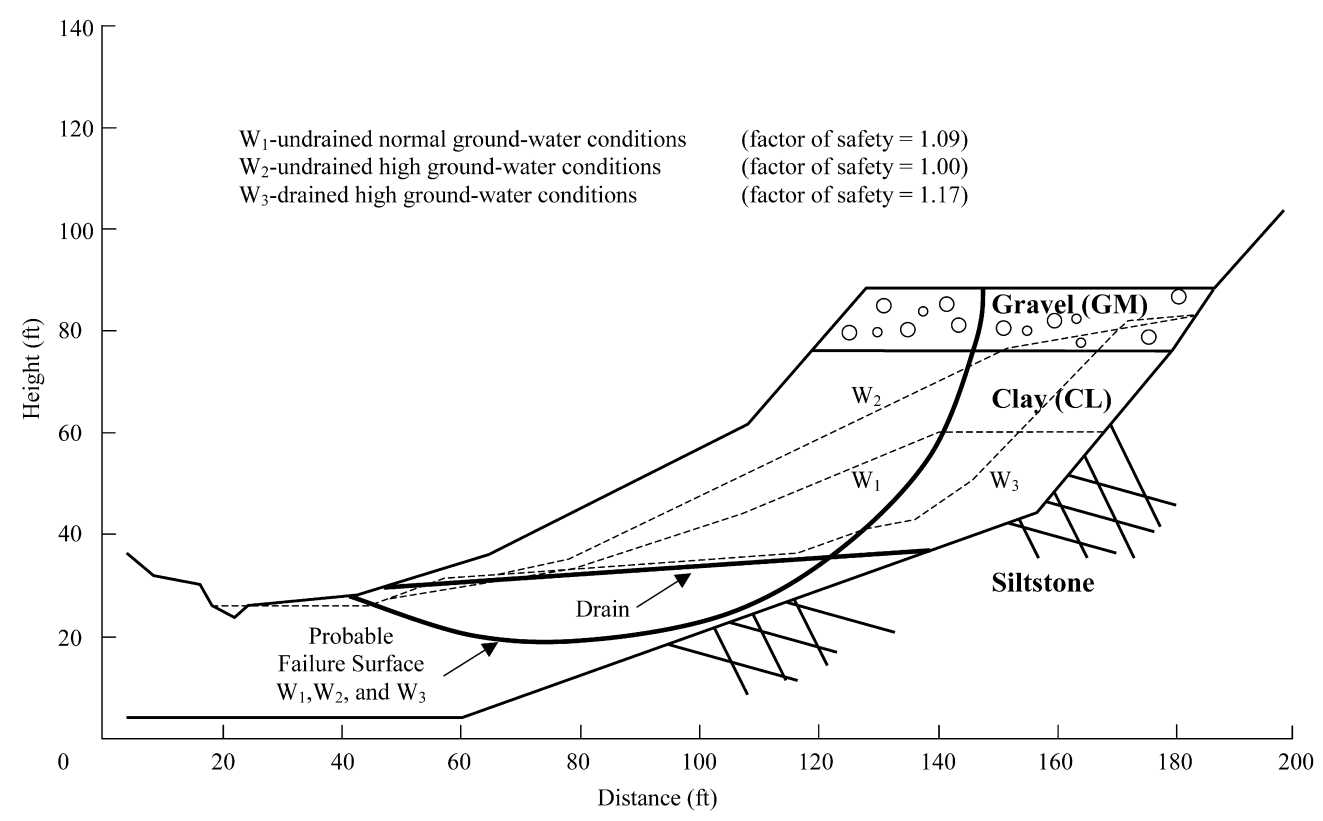

Figure 14. Analysis of the Meeker, Colorado, landslide. Lines $\mathrm{W}_{1}, \mathrm{~W}_{2}$, and $\mathrm{W}_{3}$ are the same as those defined in Figure 8. Soil properties are shown in Table 1 . 
Table 2. Calculation of footage rates from the three demonstration sites.

\begin{tabular}{|c|c|c|c|}
\hline Site & $\begin{array}{c}\text { Hours } \\
\text { Worked }\end{array}$ & $\begin{array}{c}\text { Length of } \\
\text { Drain Installed }\end{array}$ & $\begin{array}{c}\text { Rate } \\
\text { (m/hour [ft/hour]) }\end{array}$ \\
\hline Jasper, Indiana & 54.5 & $796 \mathrm{~m}(2,613 \mathrm{ft})$ & $14.6(47.9)$ \\
\hline Boonville, Missouri & 36.25 & $558 \mathrm{~m}(1,832 \mathrm{ft})$ & $15.4(50.5)$ \\
\hline Meeker, Colorado & 30.6 & $576 \mathrm{~m}(1,891 \mathrm{ft})$ & $18.8(61.8)$ \\
\hline
\end{tabular}

Backhoe and operator $=\$ 55 /$ hour

Three laborers $=3 \times \$ 20 /$ hour $=\$ 60 /$ hour

Wick drain $=\$ 1.50 / \mathrm{m}$ (varies by volume ordered)

Drive plates $=\$ 2 /$ drain (if each drain $=15 \mathrm{~m}$, then

$$
\operatorname{cost}=\$ 0.13 / \mathrm{m})
$$

Therefore, an estimated cost per meter is

$$
\begin{aligned}
& \$ 55 / 18 \mathrm{~m} / \text { hour }+\$ 60 / 18 \mathrm{~m} / \text { hour }+\$ 1.5 / \mathrm{m}+\$ 0.13 / \mathrm{m} \\
& \quad=\$ 8 / \mathrm{m}
\end{aligned}
$$

which is $\$ 2.50$ per foot.

If per-diem fees are added to this value (approximately $\$ 320$ per day), this would add approximately $\$ 2.20$ per meter to the cost, assuming production of $146 \mathrm{~m} /$ day.

\section{CONCLUSIONS}

Horizontal wick drains are an effective, economical, quick, flexible, and simple method of stabilizing landslides. The effects of drains on slope improvement can be carefully and accurately modeled using data either readily recorded in the field or derived from standard laboratory tests. Even using conservative analysis parameters, significant increases in factors of safety may be realized: increases of as much as 43 percent above high groundwater conditions and as much as 11 percent above low groundwater conditions were shown for the Jasper, Indiana, site.

Ideal slopes for the application of this method have natural water tables close to the surface and show slope movement in response to elevated water-table conditions from rainfall, snowmelt, or surface infiltration from irrigation or leakage through ditches. Wick drains may be effectively driven through clayey, silty, and sandy materials with standard penetration test values of less than 30 at lengths of up to $30 \mathrm{~m}(100 \mathrm{ft})$ using smalldiameter drive pipes and, presumably, at greater lengths using more robust pipes.

\section{ACKNOWLEDGMENTS}

Funding for this work was provided by the NCHRPIDEA Program of the Transportation Research Board (Contracts NCHRP-57 and NCHRP-76) and the University of Missouri Research Board. Test sites were stabilized in partnership with the Nilex Corporation; the American Wick Drain Corporation; the Indiana, Missouri, and Colorado Departments of Transportation; and the Colorado Geological Survey. Robert Berri, James Slosson, Robert Watters, and Terry West provided helpful comments to improve the manuscript in their capacity as reviewers.

\section{REFERENCES}

American Wick Drain Corporation, 2002, http://www.americanwick. com/amer407spec.-html (accessed on April 22, 2002).

Chase, D., 2000, personal communication, Indiana Department of Transportation, 7770 New York Street, Indianapolis, IN 46214.

Chог, Е. C. C., 1983, Seepage around horizontal drains in hill slopes: Journal Hydraulic Engineering, Vol. 109, No. 10, pp. 1363-1368.

Coduto, D. P., 2001, Foundation Design: Principles and Practice: Prentice Hall, Upper Saddle River, NJ, p. 50.

Crenshaw, B. A. AND SANTI, P. M., in press, Water table profiles in the vicinity of horizontal drains: Environmental Engineering Geoscience.

Hoek, E. AND Bray, J. W., 1981, Rock Slope Engineering, 3rd ed.: Institution of Mining and Metallurgy, E\&FN Spon, London, p. 23.

Kenney, T. C.; PAZIN, M.; AND ChoI, W. S., 1977, Design of horizontal drains for soil slopes: Journal Geotechnical Engineering Division, ASCE, Vol. 103, No. GT11, pp. 1311-1323.

LAU, K. C. AND KenNey, T. C., 1984, Horizontal drains to stabilize clay slopes: Canadian Geotechnical Journal, Vol. 21, No. 2, pp. 241249.

Liljegren, J. A., 2000, Horizontal Wick Drains: A Testing and Design Study: Unpublished M.S. Thesis, University of Missouri-Rolla, $93 \mathrm{p}$.

Luthin, J. N., 1966, Drainage Engineering: John Wiley \& Sons, New York, pp. 151-156.

NAKamura, H., 1988, Landslide control works by horizontal drainage works: In Bonnard, C. (Editor), Landslides. Proceedings of the 5th Symposium, Lausanne, Vol. 2, 965-970.

Nilex Corporation, 2002, http://www.nilex.com/prodwick.html (accessed on April 22, 2002).

NonveILLER, E., 1981, Efficiency of horizontal drains on slope stability, in Tenth International Conference on Soil Mechanics and Foundation Engineering, Stockholm, pp. 495-500.

PIHL, R., 2000, personal communication, Colorado Geological Survey, 202 Centennial Street, Glenwood Springs, CO 81601.

SANTI, P. M., 1999, Horizontal wick drains as a cost-effective method to stabilize landslides: Geotechnical News, Vol. 17, No. 2, pp. 44-46.

SAnti, P. M. AND CRENSHAw, B. A., 2002, Demonstration projects using wick drains to stabilize landslides, in Proceedings for the Rocky Mountain Section of the American Society of Civil Engineers, Denver, 8 p.

SAnti, P. M. ANd ElifRits, C. D., 2000, Highway landslide stabilization using wick drains. In Lowell, S., and Badger, T. (Symposium Cochairs), Proceedings of the 51st Annual Highway Geology Symposium, Seattle, pp. 99-106.

SAnti, P. M.; Elifrits, C. D.; And Liljegren, J. A., 2001a, Design and installation of horizontal wick drains for landslide stabilization: Civil Engineering, Vol. 71, No. 6, pp. A1-A10.

SAnti, P. M.; ElifRits, C. D.; And Liljegren, J. A., 2001b, Design and installation of horizontal wick drains for landslide stabilization: Transportation Research Record 1757, Transportation Research Board, pp. 58-66.

U.S. NAVY, 1986, Soil Mechanics Design Manual 7.1, NAVFAC DM7.1: Department of the Navy, Naval Facilities Engineering Command, Alexandria, VA, p. 149. 